\section{Can authentic leadership influence the employees' organizational justice perceptions? - a study in the hotel context}

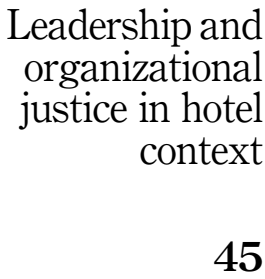

Deepu Kurian

Conrad N. Hilton College, University of Houston, Houston, Texas, USA, and
Fredrick M. Nafukho
Educational Administration and Human Resource Development,
Texas A\&M University, College Station, Texas, USA
Received 31 August 2020 Revised 21 October 2020 4 December 2020 Accepted 8 January 2021

\begin{abstract}
Purpose - The primary purpose of this study was to determine the relationship between a positive style of leadership, specifically authentic leadership, and organizational justice perceptions of employees' in the hotel industry. The following research questions guided the study: What relationship existed between hotel employees' perception toward authentic leadership and organizational justice? What relationship existed between hotel employees' perception toward authentic leadership and distributive justice, procedural justice, interactional justice and informational justice dimensions? What relationship existed among hotel employees' perception toward organizational justice, authentic leadership and their demographic background?

Design/methodology/approach - The study approached the research questions from a quantitative, nonexperimental research perspective utilizing a cross-sectional survey and descriptive correlational design, which describes the relationship or association between two or more variables in the study which are authentic leadership and organizational justice.

Findings - The results indicate that authentic leadership has a strong relationship with hotel employees' organizational justice perceptions, and authentic leadership predicted the employees' perceptions of organizational justice. Authentic leadership is a relative new leadership approach rooted in positive psychology emphasizing on the ethical and moral aspects of leadership, and the results of the study found that when employees perceive their leaders to follow the authentic leadership paradigm, they also perceive high levels of organizational justice. Authentic leadership has stronger relationships with informational and interpersonal dimensions of justice which implies that authentic leaders are strategic in their interactions with their employees. The results also imply that when employees perceive justice in terms of procedures and outcomes, they believe that organizations determine those more than their supervisors.

Research limitations/implications - The differences in the strengths of relationship between authentic leadership and structural forms of justice (distributive and procedural), and authentic leadership and interactional forms of justice (informational and interpersonal), have implications for both justice and leadership theories. The results suggest that authentic leader behaviors create a fair climate - an interpersonally and informationally fair climate which promotes all forms of justice perceptions in individual followers. However, it needs to be further researched whether leaders with high interpersonal skills and information-sharing abilities showing consideration and respect to employees may result in higher levels of organizational justice perceptions. Thus, further research is needed to determine the relationship of authentic leadership and each of the organizational justice (distributive, procedural, informational and interpersonal) dimensions, which may provide more insights as to whether leader behavior contains element of justice itself. Practical implications - The findings showcase the need for organizations in the hotel and hospitality industry to establish programs that focus on leadership practices which improve employees' perceptions of
\end{abstract}

(C) Deepu Kurian and Fredrick M. Nafukho. Published in International Hospitality Review. Published by Emerald Publishing Limited. This article is published under the Creative Commons Attribution (CCBY 4.0) licence. Anyone may reproduce, distribute, translate and create derivative works of this article (for both commercial and non-commercial purposes), subject to full attribution to the original publication and authors. The full terms of this licence may be seen at http://creativecommons.org/licences/by/4.0/legalcode

Data Availability Statement: The datasets generated and/or analyzed during the current study are available from the corresponding author on reasonable request.

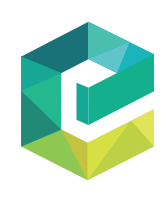

International Hospitality Review Vol. 36 No. 1, 2022 pp. $45-64$ 
IHR

36,1

organizational justice and, in turn, lead to positive organizational outcomes including reducing the considerable costs of employee turnover. It is also important that employees are aware of the policies and procedures and have a perception that they can connect and communicate to their supervisors and managers. Social implications - This study falls into the larger conversation of social justice and how an organization's leadership can be a strong associate for social justice movements by supporting equity within the organization. Originality/value - The study integrates leadership and justice theories in a hotel context. The results of this study may motivate hospitality/ hotel leaders to include authentic leadership development as an actionable strategy to bolster fairness and mitigate some of the negative features of the industry.

Keywords Organizational justice, Authentic leadership, Human resources, Hotels

Paper type Research paper

\section{Introduction}

Hotel industry is an integral part of the hospitality sector, and due to its visibility and name recognition, it has become a leading indicator of a country's lifestyle and the pillar of tourism and hospitality sector. Hospitality sector includes a broad category of fields within the service industry such as lodging, food and drink service, event planning, theme parks, transportation, cruise line, traveling and other additional fields within the tourism industry (BLS, 2019). The industry has increased its role in many countries over the world by directly contributing to gross domestic product (GDP) growth and employment generation. Additionally, research has found that hospitality industry has spillover effects which contribute to the economic and social progress, and consequently to strengthening national economies (Cut-Lupulescu et al., 2014).

Hotel industry is highly labor-intensive, with diverse employees from various backgrounds and life experiences. For instance, hotels provide employment for highly qualified individuals along with positions that only require basic skills and low educational qualifications such as a high school diploma. In the United States and many other nations, the hotel industry provides employment for the elderly population and opportunities for immigrants and for groups with difficulties to access the formal labor market. Despite these distinctive features, the hotel industry is often noted for poor working conditions, extended working hours, lower pay, limited or no health insurance and high employee turnover (Carbery et al., 2003). Continuous pressure from management and customers to provide unique and exemplary service and negative working conditions are major factors of dissatisfaction for hotel employees (Megeirhi et al., 2018). Carbery et al. (2003) found that the aftereffects of such dissatisfaction are notoriously high turnover rate and contempt for working conditions. Additionally, attitudes of hotel employees at work are especially critical because of the high degree of personal contact with customers/guests and the behaviors necessary for providing exceptional service to their patrons (Fulford, 2005).

Berger et al. (1993) predicted that organizational justice would be a major influence in determining employer-employee relationships within the hospitality industry in the 21st century. Organizational justice refers to the extent to which employees perceive workplace procedures, interactions and outcomes to be fair (Baldwin, 2006). More recent research focusing on hospitality industry has shown that the predictions were true to a great extent, and employee's perception of justice at the workplace is a significant factor in many organizational outcomes including their intention to stay (Gosser et al., 2018; Luo et al., 2017). Similarly, researchers over the years have consistently argued that future direction of leadership research must move away from a hierarchical, leader-centric approach to a more integrative and positive approach (Avolio, 2007; Dinh et al., 2014; Meindl, 1989). Authentic leadership, often considered as an antecedent to all other forms of positive leadership (Avolio and Gardner, 2005), is defined as "a pattern of leader behavior that draws upon and promotes both positive psychological capacities and a positive ethical climate to foster greater self-awareness and internalized moral perspective, balanced 
processing of information, and relational transparency on the part of leaders working with followers, fostering positive self-development" (Walumba et al., 2008, p. 94). Building upon this general conceptual argument for leadership as an antecedent to justice perceptions, this study attempted to articulate that authentic leadership style can create high levels of fairness perceptions in subordinates.

According to Karam et al. (2019), an increased understanding of the relationships between leadership and justice perceptions is important for two reasons: (1) "Employee-leader relationships are often characterized as social exchange relationships and are distinguished from other forms of exchanges by having expectations of longer-term, interdependent interactions that generate trust, reciprocal behaviors, and high-quality relationships," (p. 136); and (2) "Leader-focused justice commonly focus on research questions related to either (a) investigating the unique effects of leader-focused justice dimensions (i.e. procedural, distributive, interpersonal, informational justice) on organizational outcomes, or (b) exploring how(un)fair treatment attributed to a leader is similar to or different from (un)fair treatment attributed to others" (p. 137). While the constructs of authentic leadership style and organizational justice are well established and have high levels of research activity, those streams of research are more independent. Research on justice and positive leadership has found that positive leadership and levels of organizational justice are positively related to positive organizational and employee outcomes (Avolio et al., 2009; Kiersch and Byrne, 2015). Thus, there is a need for higher integration of leadership and organizational justice research, and this study addresses that critical need.

\section{Problem statement}

High turnover rate is a universal problem in the hotel industry (Faldetta et al., 2013), and the global yearly turnover rate in hotel industry can vary from 60 to $300 \%$, which is much higher compared to that in the manufacturing industry (Hemdi and Rahim, 2011). Scholars who studied the hotel industry have suggested that the long-term solutions for the turnover problem can be found in the constructs of leadership and organizational justice (Baum, 2013; Fulford, 2005; Luo et al., 2017). Extant research has suggested that having committed employees who are satisfied with their work and working conditions and who feel that they are treated fairly in their workplace is important to the success and bottom-line of their organization (López-Cabarcosb et al., 2015).

Research across various continents suggested that hotel industry still relies on traditional leadership styles: from transactional or autocratic (Ispas, 2012), to laissez-faire (Yamak and Eyupoglu, 2018), to paternalistic or authoritarian (Tran, 2017), and leader-member exchange (Garg and Dhar, 2016). Supervisors and managers have the most interactions with employees, and extant research has found that supervisor's leadership that values employees, provides them with a respectable working environment, treats them with fairness and ensures selfdevelopment can counter the ill effects of working in the hotel industry. Meindl (1989) observed, "... an image of managers as interested in justice and the fair treatment of subordinate others in the execution of their roles is one that should be, but often is not represented or taken seriously" (p. 272). Authentic leadership (AL) has been viewed as an attractive leadership model to combat destructive forms of leadership (Storberg-Walker and Gardiner, 2017). Moreover, leadership styles that cause employees to focus on justice will strengthen justice's effect on an employee's resulting behavior, whereas those leadership styles that channel employees' attention away from justice issues will, in contrast, diminish the justice-behavior relationship (Strom et al., 2014). According to social contagion theory, when employees perceive the leader as being genuine, reliable, ethical and consistent over time, a contagion effect occurs, diminishing the tendency of negative attitudes and behaviors (Luthans et al., 2006; Avolio et al., 2004). 
IHR

36,1

48

\section{Purpose of the study and research questions}

The primary purpose of this study was to determine the relationship between a positive style of leadership, specifically authentic leadership and organizational justice perceptions of employees in the hotel industry. The following research questions guided the study:

(1) What relationship exists between hotel employees' perception toward authentic leadership and organizational justice?

(2) Is there any difference in the relationship between authentic leadership and hotel employees' perceptions toward different dimensions of organizational justice, namely, distributive justice, procedural justice, interactional justice and informational justice?

(3) Did any demographic factors influence the relationship between authentic leadership and hotel employees' perception toward organizational justice?

\section{Review of relevant literature}

Leadership and organizational justice

Leadership and organizational justice are two of the most widely researched topics in social science and management (Colquitt et al., 2005; Hiller et al., 2011). Research across various continents suggested that hotel industry still relies on traditional leadership styles: from transactional or autocratic (Ispas, 2012), to laissez-faire (Yamak and Eyupoglu, 2018), to paternalistic or authoritarian (Tran, 2017) and to leader-member exchange (Garg and Dhar, 2016). Luo et al. (2017) found that hotel supervisors or middle-level managers have the most interactions with frontline employees, and their leadership practices influenced employees' attitudes, behaviors and performance. An ideal leader is the one who can lead with integrity and values, can motivate employees and manage a healthy organization that creates value for all employees, customers and stakeholders (Pless and Maak, 2011). In addition, society now demands that organizational business leaders not only generate a profit but maintain high levels of integrity, morality and fairness while doing so (Hannah et al., 2011; Kiersch and Byrne, 2015; Walumbwa et al., 2008). Positive forms of leadership are gaining traction in academic and professional literature, and authentic leadership is one of such new themes which represent a relatively new leadership framework stemming from the fields of leadership, ethics, positive psychology and positive organizational behavior (Avolio et al., 2004; Walumbwa et al., 2008).

\section{Authentic leadership}

Times are changing and so are people's views on leadership. Successful leadership remains a key success factor for organizations; especially when their employees are motivated by that leadership to achieve organizational goals (Tsai et al., 2009). Economic, social, geopolitical and technological developments have placed demands on leaders and requires them to be more transparent, have increased awareness of their actions and guide organizations with a moral/ethical perspective (Clapp-Smith et al., 2009). Several researchers agree that future direction of leadership research must move away from a hierarchical, leader-centric approach to a more integrative and positive approach (Avolio, 2007; Dinh et al., 2014; Meindl, 1989). Youssef-Morgan and Luthans (2013) defined positive leadership as "the systematic and integrated manifestation of leadership traits, processes, intentional behaviors and performance outcomes that are elevating, exceptional and affirmative of the strengths, capabilities and developmental potential of leaders, their followers and their organizations over time and across contexts" (p. 199). Authentic leadership is a widely studied form of positive leadership. It is also viewed as an antecedent to all other forms of positive leadership 
including transformational, ethical and servant leadership (Avolio and Gardner, 2005). Over the years, authenticity has become the gold standard for leadership; however, a simplistic understanding of authenticity can hinder the leader's growth and limit their impact (Ibarra, 2015).

Authentic leadership represents a relatively new leadership framework stemming from the fields of leadership, ethics, positive psychology and positive organizational behavior (Avolio et al., 2004; Luthans and Avolio, 2003). Hannah et al. (2011) noted that theorists, practitioners and researchers who worked to shape the concept of authenticity in leadership focused on the leadership qualities, fostering hope and optimism concerning collective goals. It is a general understanding that authentic leadership occurs when individuals enact their true selves in their roles as a leader (Leroy et al., 2015). Authentic leadership behavior refers to the extent to which the leader is aware of and exhibits a pattern of openness and clarity and is consistent in their disclosure and enactment of personal values, motives and sentiments (Walumbwa et al., 2008). George (2003) described authentic leaders as those who are high in integrity and purpose, have unwavering core values and show a strong commitment to all stakeholders (Gardner et al., 2005; Luthans and Avolio, 2003). Northouse (2018) proposed three different viewpoints about authentic leadership - the intrapersonal perspective which focuses on the leader and what goes on within the leader; the interpersonal perspective which outlines authentic leadership as a relational process by leaders and followers together; and the developmental perspective which views authentic leadership as something that can be nurtured in a leader, rather than as a fixed trait.

\section{Organizational justice}

The origin of organizational justice research is rooted in moral philosophy that focuses on what societies should do and how people should treat each other and which has evolved into social science treatments of how people form judgments about such norms and react to perceived violations of perceived norms (Rupp et al., 2017). Social scientists have long recognized the importance of the ideals of justice as the basic requirement for the effective functioning of organizations and the personal satisfaction of the individuals they employ (Greenberg, 1990). Organizational justice has always been a major focus of research due to its connection with numerous employee outcomes: satisfaction, commitment, engagement, trust and reduced levels of turnover (Martinson et al., 2010).

Drawing from the works of Homans (1958) and Adams (1965), distributive justice is considered as the original concept of organizational justice which deals with the fairness of outcomes including pay, rewards and promotion (Colquitt et al., 2005). Thibaut and Walker (1975) conducted a series of studies on the fairness of decision-making processes, which contributed to the development of procedural justice. Thus, procedural justice is concerned with fairness issues about the processes used to determine outcomes. Bies and Moag (1986) observed that decision events have three facets: a decision, a procedure and an interpersonal interaction during which that procedure is implemented. This led to the development of third dimension - interactional justice - which refers to the fairness of interpersonal interaction. Bies and Moag argued that that interactional justice was fostered when relevant authorities communicated procedural details in a respectful and proper manner and justified decisions using honest and truthful information. Some scholars expanded the communication criteria in interactional justice to a fourth dimension - informational justice - which focused on justification and truthfulness in communication. In an organization, members interact with each other, observe each other's behavior and engage in collective sense-making, a tendency that may ultimately lead to the development of shared perceptions on how to evaluate justicetriggering events (Naumann and Bennett, 2000). As Umphress et al. (2003) stated, "justice perceptions are not formed in isolation; rather, they are subject to the influences of those with whom we interact" (p. 739). 
IHR

36,1

All types of justice perceptions have been associated with a wide range of positive organizational outcomes in the literature. In their meta-analytic review, Cohen-Charash and Spector (2001) showed justice perceptions to be positively related to job performance (i.e. role performance) as well as organizational citizenship behaviors (i.e. extra-role performance, going beyond the job requirements to help the organization). Justice perceptions are also associated with positive organizational attitudes, including organizational commitment (Colquitt et al., 2001), job satisfaction (Greenberg, 2011) and inversely related to employee burnout, turnover and work-related stress (Fox et al., 2001; Judge and Colquitt, 2004). It is evident from the extant literature that organizational justice plays an important role in the organization, the organizational outcomes and relationships within the organization.

\section{Theoretical foundations}

An established theoretical framework for explaining how people's reactions to justice may vary depending on a leader's behavioral style is leader fairness theory, also known as the contingency approach to leadership and fairness (De Cremer, 2006; De Cremer and Tyler, 2011). This theory posits that a leader's style will direct employees' attention either toward or away from matters of organizational justice (Strom et al., 2014). The authentic leader models the way and ensures justice and fairness, because authentic leaders fully embrace the imperative of a healthy workplace environment, authentically live it and engage others in the achievement (Kerfoot, 2006). According to fairness theory, moral accountability is a central feature to organizational justice and the formation of fairness judgments, and justice perceptions are largely grounded in basic moral and ethical assumptions regarding how others should be treated (Folger and Cropanzano, 2001; Folger et al., 2005). According to May et al. (2003), authentic leaders are those who have developed the ability to make decisions and behave in ways that are ethically responsible to their stakeholders and have a high level of moral perspective to recognize and successfully evaluate ethical issues. In sum, morality is theorized to be at the heart of authentic leadership and is also a critical component of organizational justice, and this common foundation is proposed as one key reason why authentic leadership should predict high levels of organizational fairness. Exchange relationships cannot develop in the absence of trust (Blau, 1964) which is a common factor in the constructs of organization justice and authentic leadership. Studies have found that employee's perception of organizational trust enhances when they are treated fairly, and employees' trust in their leader is associated with their positive attitudes and behavior (Avolio et al., 2004). Because authentic leaders exemplify high moral standards, integrity and honesty, their favorable reputation fosters positive expectations among followers, enhancing their levels of trust and willingness to cooperate with the leader for the benefit of the organization

\section{Methods}

The study approached the research questions from a quantitative, non-experimental research perspective utilizing a cross-sectional survey and descriptive correlational design, which describes the relationship or association between two or more variables in the study, which are authentic leadership and organizational justice (Drummond and Murphy-Reyes, 2018).

\section{Study sample and sample selection}

The target population for this study comprised of employees working in hotel industry in the United States. The sample selection for this study can be classified under the general category of cluster sampling. Respondents for this study were recruited in two ways. Firstly, the study subjects including undergraduate and graduate students enrolled in hospitality management 
courses and employed in hotels were invited to participate in the study. Snowball sampling (Berg, 2006) was utilized, and qualified study subjects were requested to share the invitation with other subjects like them who met the criteria defined for the targeted population. Secondly, leaders of professional / trade organizations in hotel industry (Greater Houston Hotel and Lodging Association and Texas Hotel and Lodging Association) were contacted through common acquaintances. The organization's leaders were appraised of the purpose of the study and its relevance, and upon their agreement, an email invitation to participate in the study was forwarded to all members in the organization by the organizational leaders. The organizations' membership consisted of hotel organizations in the state of Texas. The online survey took approximately 15 min to complete and was accessible from any computer with an Internet connection.

\section{Instruments for data collection}

The data for this study were collected using electronic surveys administered to hotel employees in the United States. The Authentic Leadership Questionnaire (ALQ) was adopted to assess self- or other-rated perceptions of authentic leadership behavior and is copyrighted. The permission to use the instrument was obtained from Mindgarden Inc. Organizational justice was measured using Colquitt's 20-item organizational justice scale, which is available in the public domain.

\section{Validity and reliability of the instruments}

When searching for an appropriate survey instrument, Cronbach's alpha coefficient is one of the most frequently reported statistic used to measure reliability. Previous studies utilizing the ALQ have consistently reported Cronbach's alpha of around 0.90 for authentic leadership (Kiersch and Byrne, 2015; Rego et al., 2012; Walumbwa et al., 2008) which denotes excellent to high reliability. Similarly, previous studies have consistently reported Cronbach's alpha for the four dimensions of organizational justice falls around 0.85 to 0.93 (Kiersch and Byrne, 2015; Nadiri and Tanova, 2010; Ambrose and Schminke, 2009). Colquitt's (2001) initial scale development and validation study provided evidence of construct validity via predictive validity, and the wide body of justice research in the past decade has further strengthened the evidence for these four scales as valid measures of the four intended justice types distributive, procedural, interactional and informational (Greenberg, 2011). The two instruments used in this study had been previously validated independently, but they were combined in this study. Therefore, it was prudent to use exploratory factor analysis (EFA) to cross-validate the instruments in order to consider possible changes to the internal structure of the constructs. In this study, EFA was deemed appropriate because the items drawn from previously validated instruments were being used in a unique context and had not previously been studied in conjunction with each other.

\section{Data collection procedures}

The survey email was directly sent to 420 participants with a request to forward the survey to any hotel employees. Of the study subjects contacted, 264 individuals responded to the survey, of which 92 were incomplete/ partial responses. The study's conceptual model was tested with data from employees working in the hotel industry in the United States, who responded to survey questions regarding their perceptions of their direct supervisor's leadership and level of fairness in organizations. Direct supervisors were chosen as the leaders in this study because research has shown that an employee's immediate supervisor is a greater determinant of employee behavior than higher-level organizational leaders due to frequency in interaction and direct influence on each employee's work experience 
IHR

36,1

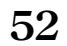

(De Coninck, 2010; Pillai et al., 1999). Respondents rated their direct supervisor in terms of perceived authentic leadership using the 16-item ALQ (Avolio et al., 2007).

The survey completion rate of those who participated in the survey was $65.15 \%(n=172)$. The sample included 75 males and 96 females, that is, $43.60 \%$ and $55.81 \%$, respectively. One participant $(0.58 \%)$ selected the non-binary gender. The age range of participants that had the highest level of participation was 18-34 years $(n=122,70.93 \%)$, followed by $35-50$ $(n=33,19.19 \%)$. Most of the study participants were White $(n=71,41.52 \%)$, followed closely by Asian $(n=49,28.65 \%)$ and Hispanics $(n=41,23.98 \%)$. The maximum response for education-level attainment for hotel employees who responded to this survey was 4 years college ( $n=81,47.09 \%)$. For organizational tenure, 66 participants $(38.37 \%)$ were employed with the organization for 4-10 years, which was closely followed by $65(37.79 \%)$ participants who stated their experience was between 0 and 3 years; 69.05 percent $(n=116)$ of the participants reported that they worked in the front of the house, with high guest interaction, while the rest worked in the back of the house, with minimal to no guest interaction.

\section{Results}

Even though validity and reliability had been previously established for each of the instruments used in this study, an EFA was conducted to determine how the items utilized in this study related or loaded onto various constructs. Kaiser-Meyer-Olkin (KMO) measure of sampling adequacy and Bartlett's test of sphericity were utilized to ensure whether the sample data met minimum criteria for factor analysis. Hutcheson and Sofroniou (1999) stated that values between 0.5 and 0.7 are mediocre, values between 0.7 and 0.8 are good, values between 0.8 and 0.9 are great and values above 0.9 are the best. The KMO for the combined items $(\mathrm{KMO}=0.944)$ in this study exceeded the 0.9 value; therefore, factor analysis is appropriate for these data. Similarly, a significant Bartlett test implies that the correlation matrix is not an identity matrix; therefore, there are some relationships between the variables that can be included in the analysis (Tabachnick and Fidell, 1996). For these data, Bartlett's test is highly significant $(\phi<0.001)$, and therefore factor analysis is appropriate.

Communalities were inspected to determine how well the solution (i.e. the constructs extracted) accounted for the variance of each item. The communalities in the column labeled extraction reflect the common variance in the data structure. Communalities exceeded the minimum criterion value of 0.30 (Warner, 2013), indicating that the variance in each item was sufficiently captured in the factor solution. EFA, via principal components analysis with varimax rotation, produced five constructs, each with an eigenvalue equal to or greater than 1 , for the combined 36-item survey. The first five components cumulatively account for the major proportion of the total variance $(75.22 \%)$. However, as seen from Table 1 , rotation has the effect of optimizing the factor structure, and one consequence for the data is that the relative importance of the five factors is equalized. Before rotation, component one accounted for considerably more variance than the remaining four (54.04\% compared to 9.35, 5.02, 3.69 and $3.12 \%$ ), but after rotation, component one accounted for only $17.23 \%$ of variance (compared to 16.88, 15.68, 15.04 and 10.38\%, respectively). For this study, all observed components with eigenvalues larger than their corresponding random eigenvalues are considered "significant," and thus defined a valid dimension and were included.

Even though the factor matrix did not have a clean factor structure, the factor loadings for the survey items clearly loaded onto distinct factors, the rotated component matrix for loadings across the five constructs. The factor loading values below 0.45 were suppressed, and cross-loading was reported for couple items, but there was no major cross-loading. The rotation confirmed that there were two constructs as originally proposed, but items did not load in each construct as expected for the dimensions of organizational justice. After carefully reviewing the items that loaded differently, the researcher decided to interpret the items to the 


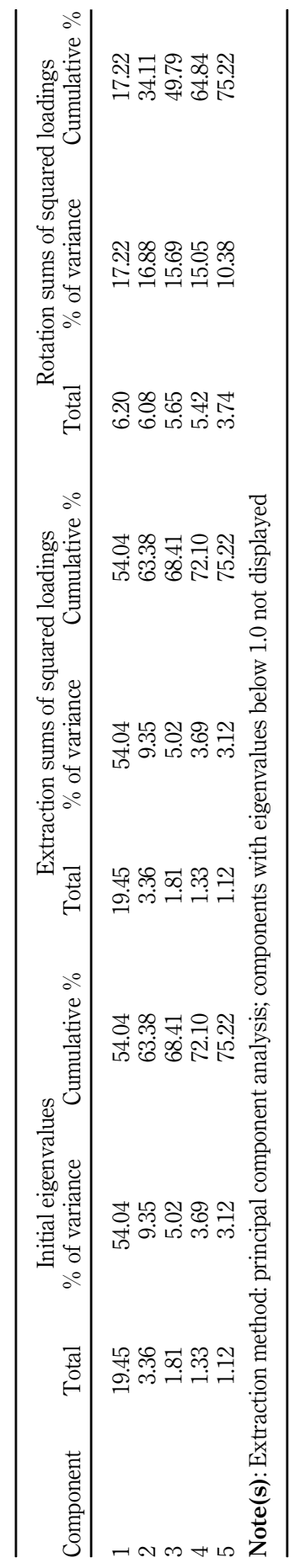

Leadership and organizational justice in hotel context

53

Table 1.

Total variance explained 
IHR

36,1

original dimensions of organizational justice. Thus, based on the results of the EFA and review by the researcher, all the 36 items represented in the two original constructs of authentic leadership and organizational justice were retained. As far as internal consistency of the scale is concerned, the analysis of authentic leadership scale indicates high degrees of internal consistency (Cronbach's alpha $=0.962$ ). Similarly, organizational justice and its dimensions showed high levels of internal consistency, with Cronbach's alpha ranging from 0.926 to 0.966 .

Authentic leadership and organizational justice showed a strong degree of correlation $\left(r=0.720^{* *}\right)$ which means that those who have a high perception of their supervisor authentic leadership tend to have a higher perception of organizational justice. It is not surprising to have strong correlation between age and work experience $(r=0.791 * *)$, because as age increases, the work experience also increases. All other significant relationships (educational level and age, work experience and educational level, functional area and ethnicity, work experience and authentic leadership, and functional area and educational level) showed a weak or very weak degree of correlation.

The relationship between authentic leadership and distributive justice shows a moderate degree of positive correlation at 0.51 , with a confidence interval of $95 \%$ and a statistical significance of $p \leq 0.01$. The higher perceptions of authentic leadership only resulted in a moderate degree of distributive justice perceptions. The relationship between authentic leadership and distributive justice was the lowest when compared to other organizational justice dimensions. The relationship between authentic leadership and procedural justice shows a strong degree of positive correlation at 0.61 , with a confidence interval of $95 \%$ and a statistical significance of $p \leq 0.01$. Thus, it can be said that those who have higher perceptions of authentic leadership tend to have strong perceptions of procedural justice in the organization. The relationship between authentic leadership and informational justice shows a strong degree of positive correlation at 0.77 , with a confidence interval of $95 \%$ and a statistical significance of $p \leq 0.01$. The relationship between authentic leadership and informational justice was the highest in comparison with other justice dimensions. The relationship between authentic leadership and interpersonal / interactional justice shows a strong degree of positive correlation at 0.65 , with a confidence interval of $95 \%$ and a statistical significance of $p \leq 0.01$.

Before conducting a regression analysis, the following assumptions for multiple regression were tested. The assumption of linearity should be met because regression model assumes a linear relationship between the independent and dependent variable. According to scatterplot, the independent variable (authentic leadership) has a linear relationship with the dependent variable (organizational justice). The assumption of minimal multicollinearity should be met because it means that independent variables should not be highly correlated with each other in order to better predict the dependent variable in the model. As shown in correlation matrix in Table 2, the independent variables do not highly correlate with each other. Also, the variance inflation factor (VIF) value is one (1) and the value of tolerance is also one (1), which eliminate the assumption of multicollinearity. Finally, the assumption of homoscedasticity should be met, which means that the variability of residual errors should be the same across all possible predicted values of the dependent variable. The scatterplot does not show a pattern or unusual vales, which means the residuals are randomly scattered.

A regression analysis was conducted to analyze the difference in relationship between authentic leadership and the different dimensions of organizational justice taken independently. As evident from Table 2, authentic leadership accounted only for $25.4 \%$ (adjusted $R$ square $=0.254$ ) of the variance in distributive justice, while authentic leadership accounted for $59.2 \%$ (adjusted $R$ square $=0.592$ ) of variance in informational justice. 
As inferred from Table 2, hotel employees perceive authentic leaders exhibit high levels on informational and interactional justice (individual focused) when compared to distributive and procedural justice (organization focused).

Hierarchical regression was conducted to show whether the demographic and independent variables explained a statistically significant amount of variance in the dependent variables. The hierarchical multiple regression was conducted in two steps. First, all the demographic variables age, gender, ethnicity, education, experience and functional area were entered. In the second step, organizational justice was included. The model summary is depicted in Table 3 . The multiple regression model with all seven predictors (Model 2) produced an adjusted $R^{2}=0.569, F(7,158)=29.823$, with a significance level of $p<0.001$. However, Model 1 with the demographic variables alone produced an adjusted $R^{2}=0.023, F(6,159)=1.646$ and were not significant at $p<0.05$. As evident from the models, the demographic variables were not statistically significant in predicting organizational justice. But when authentic leadership was added as the predictor (Model 2), it accounted for $55 \%$ (adjusted $R$ square $=0.550$ ) of the variance in organizational justice perception of hotel employees. Thus, the results of the hierarchical multiple regression analyses showed that all the independent variables in this study accounted for approximately $55 \%$ of the variation in organizational justice perceptions among hotel employees. By analyzing the coefficients presented in Table 3, on Model 1, only one demographic variable, gender, was found to be statistically significant $(\beta=0.161, t=-2.034, p=0.044)$. However, in Model 2 , the coefficient table shows two demographic variables as statistically significant: work experience

\begin{tabular}{|c|c|c|c|c|c|}
\hline Model & $R$ & $R$ square & Adjusted $R$ square & Std. error of the estimate & \\
\hline Distributive justice & 0.508 & 0.258 & 0.254 & 0.96747 & \\
\hline Procedural justice & 0.606 & 0.368 & 0.364 & 0.83534 & \\
\hline Informational justice & 0.771 & 0.595 & 0.592 & 0.70950 & Table 2. \\
\hline Interactional justice & 0.650 & 0.422 & 0.418 & 0.82047 & Regression model \\
\hline
\end{tabular}

\begin{tabular}{|c|c|c|c|c|c|c|c|}
\hline \multirow{2}{*}{$\frac{\text { Model }}{1}$} & \multirow{3}{*}{$\frac{R}{0.242}$} & \multirow{3}{*}{$\begin{array}{c}R \text { square } \\
0.058 \\
B\end{array}$} & \multicolumn{2}{|c|}{ Adjusted $R$ square } & \multicolumn{2}{|c|}{$\begin{array}{c}\text { Std. error of the } \\
\text { estimate }\end{array}$} & \\
\hline & & & \multicolumn{2}{|c|}{0.023} & \multicolumn{2}{|c|}{0.93209} & \\
\hline & & & Std. error & Beta & $t$ & Sig & \\
\hline & (Constant) & 4.440 & 0.375 & & 11.850 & 0.000 & \\
\hline & Age category & -0.091 & 0.181 & -0.064 & -0.506 & 0.613 & \\
\hline & Gender & -0.286 & 0.140 & -0.161 & -2.034 & 0.044 & \\
\hline & Ethnicity & -0.013 & 0.023 & -0.047 & -0.580 & 0.563 & \\
\hline & Educational level & 0.014 & 0.088 & 0.013 & 0.163 & 0.870 & \\
\hline & Work experience & -0.049 & 0.121 & -0.051 & -0.406 & 0.685 & \\
\hline & Functional area & -0.263 & 0.171 & -0.130 & -1.536 & 0.126 & \\
\hline \multirow[t]{9}{*}{2} & 0.754 & 0.569 & \multicolumn{2}{|c|}{0.550} & \multicolumn{2}{|c|}{0.63248} & \\
\hline & (Constant) & 1.965 & 0.312 & & 6.298 & 0.000 & \\
\hline & Age category & 0.150 & 0.124 & 0.106 & 1.211 & 0.228 & \\
\hline & Gender & -0.143 & 0.096 & -0.080 & -1.487 & 0.139 & \\
\hline & Ethnicity & -0.010 & 0.016 & -0.034 & -0.628 & 0.531 & \\
\hline & Educational level & 0.081 & 0.060 & 0.076 & 1.361 & 0.175 & Table 3. \\
\hline & Work experience & -0.299 & 0.084 & -0.312 & -3.561 & 0.000 & Hierarchical multiple \\
\hline & Functional area & -0.233 & 0.116 & -0.115 & -2.006 & 0.047 & regression model and \\
\hline & Authentic leadership & 0.779 & 0.057 & 0.741 & 13.686 & 0.000 & coefficients \\
\hline
\end{tabular}


IHR

36,1

$(\beta=0.312, t=3.561, p=0.000)$ and functional area $(\beta=0.115, t=2.006, p=0.047)$. The coefficient table shows authentic leadership as a significant predictor of organizational justice in model $2(\beta=0.741, t=13.686, p=0.000)$.

Thus, the coefficients of variables indicate that we would expect an increase of 0.78 in the organizational justice perceptions for everyone unit increase in authentic leadership perceptions, assuming that all other variables in the model are held constant. Similarly, one standard deviation increase in authentic leadership would yield a $0.74(\beta=0.741)$ standard deviation increase in predicted organizational justice perception. As inferred from Table 3, authentic leadership had significant positive progression weights, indicating that when hotel employees perceive their leaders to be authentic, they are expected to have higher perceptions of organizational justice.

\section{Discussion}

As shown by the results of this study, the relationship between the supervisor and employee was a determining factor for employees in creating perceptions about fairness and justice in their employing organization. Therefore, maintaining a supervisor - subordinate relationship which is conducive of creating a productive work environment - is important for most organizational outcomes. The challenge for many organizations is to ascertain which leadership style is appropriate for their environment, and which leadership style and/ or behavior will produce better outcomes including the perception of a just workplace. The results illustrate that the relationship between authentic leadership and hotel employee's organizational justice perceptions in the study was significant and exhibited a strong degree of positive correlation. That is, the more the employees perceive that their leaders to be authentic, the more they are satisfied with the organizational procedures and outcomes such as pay, performance and promotion. This is not surprising because employee's relationship with the leader is the most powerful connection that an employee can build in an organization (Hui et al., 2004) and that relationship often determines the employee's perceptions of organizational justice (Colquitt et al., 2013).

The relationship between authentic leadership and employees' perceptions of distributive and procedural justice is significant and shows a moderate to strong degree of positive correlation. Among the relationships between authentic leadership and dimensions of organizational justice, the weakest correlation was between authentic leadership and distributive justice followed by the relationship between authentic leadership and procedural justice. Thus, the results support prior research that employees view the resource allocation decisions and guidelines for procedures are established and controlled by the organization rather than by their supervisors. However, the positive correlation and significance suggest that hotel employees perceive their leaders to have some influence on organization-focused justice (distributive and procedural). The results from this study reaffirmed the fact that leaders are viewed as organization's agents who maintain and promote fairness (Demirtas, 2015), and employees may expect that their behaviors have an important role to play in affecting organizational procedures and outcomes. Similarly, authentic leadership emphasizes on adherence to organizational policies and practices in a consistent manner, which may influence employees' perception to the organization's fair procedures. Thus, this study results allow an inference to be made that employees working under authentic leadership perceive their organizational procedures and outcomes in a more favorable manner.

The significant and strongest correlation from the study was between authentic leadership and informational justice perception followed by the relationship between authentic leadership and interactional justice. Extant literature (Byrne et al., 2012; Neubert et al., 2009) has suggested that managers may have the greatest impact on overall fairness 
perceptions by focusing on the fairness of their personal interactions with subordinates (i.e. interactional and informational justice). The correlation and regression analysis support the existing research by showing strong correlations between authentic leadership and interactional forms of justice (informational and interactional). This may be due to the reason that supervisors are most likely to influence employees through their daily interactions and information sharing. Previous research also suggested that high levels of interactional/ interpersonal and informational justice can compensate for low levels of distributive and procedural justice (Cropanzano et al., 2007; Greenberg, 2006), further bolstering the influence of direct supervisors on interactional and informational justice. The results of the study support this notion by showing the relationship between organizational justice to be stronger than distributive and procedural justice. Thus, this study results allow an inference to be made that stronger relationship of authentic leadership with interpersonal and informational justice compensated for moderate relationship at distributive and procedural dimensions.

The results indicate that controlling for demographic variables, employees' perception about supervisor's authentic leadership is a significant predictor of employees' organizational justice perceptions. Prior research has suggested that a leader's style (Strom et al., 2014) may be responsible for directing employees' attention either toward, or away from, matters of organizational justice. The data and results of this study support the above-mentioned and suggest that supervisors who are authentic, who give employees a voice and who are interested in a transparent and just workplace promote the perceptions of justice in workplace. The results support Greenberg's (2011) suggestions for encouraging organizational justice in the workplace, namely, providing workers adequate compensation, allowing employees a voice to speak out and be heard and listened to, showing transparency in implementing and carrying out fair procedures, telling decisions in a manner that shows dignity and respect for the person and instilling in employees what it means to be fair through training, case studies and exercises to increase their sensitivity to justice at work. The results also support Kiersch and Byrne's (2015) finding that being an authentic leader often means being a fair leader, and that one way in which authentic leadership has a positive impact on team members and team outcomes is via perceptions of fair treatment (organizational justice) among the employees.

\section{Theoretical implications}

This study responds to the research direction provided by Karam et al. (2019) that future researchers should examine whether moral/ ethical leader behaviors have significant implications for justice perceptions and subsequently their joint effects in organizational outcomes due to the connection between leader's ethics-related judgments and organizational justice perceptions. Further research is required to understand what aspects of authentic leadership relate to the different dimensions of organizational justice and whether a relationship exists between different aspects of authentic leadership and the dimensions of organizational justice.

The differences in the strengths of relationship between authentic leadership and structural forms of justice (distributive and procedural), and authentic leadership and interactional forms of justice (informational and interpersonal), have implications for both justice and leadership theories. The results suggest that authentic leader behaviors create a fair climate - an interpersonally and informationally fair climate which promotes all forms of justice perceptions in individual followers. However, it needs to be further researched whether leaders with high interpersonal skills and information-sharing abilities showing consideration and respect to employees may result in higher levels of organizational justice perceptions. Thus, further research is needed to determine the relationship of authentic 
IHR

36,1

\section{8}

leadership and each of the organizational justice (distributive, procedural, informational and interpersonal) dimensions, which may provide more insights as to whether leader behaviors contain element of justice itself. Finally, it can be argued that even though leadership literature highlights authentic leadership as a positive form of leadership focusing on certain aspects of leadership (values, convictions, morality and ethics), it may simply be an internal attribution based on the organizational environment which employees perceived to be fair. As such, authentic leadership may be more of an impression related to the organizational environment, and the consistency and predictability of a leader's behavior rather than a positive impression of the leader's personal traits or values.

\section{Practical implications}

The conceptual argument that authentic leadership leads to increased levels of justice perceptions was empirically supported by this study across all justice dimensions. The study results also show that hotel employees perceive higher levels of informational and interpersonal justice in comparison with distributive and procedural justice. That would mean that employees who participated in this study perceived the distribution of outcomes and the procedures followed to reach the outcomes in a less favorable manner. Hotel industry is notorious for long working hours and low pay, and the study results may be another reflection of the reality. When employees perceive distributive justice, they weigh their inputs against the distribution of rewards and the rewards received by other employees. Therefore, leaders in the hotel industry must endeavor to allocate rewards as fair as possible across individuals. Similarly, hotel managers should make sure that the procedures used to make decisions are fair and that employees are made aware of the procedures before allocation of rewards is done.

Given that this study has shown strong relationships between authentic leadership and employees' organizational justice perceptions, human resources development (HRD) practitioners should review the results of this study relevant to practice. Research (Cottrill et al., 2014) found that organizations can promote inclusive environments through authentic leadership, and that inclusive environments promote employees' work-related self-esteem and their willingness to go above and beyond in their jobs. Thus, an authentic leadership development program will benefit leaders to practice behaviors that would display high levels of respect and mindfulness to followers and encourage them to follow practices that will positively impact the bottom-line of the organization. Finally, the relationship between authentic leadership and organizational justice as evidenced from this study calls for an increased focus on ethics in organizations. Authentic leadership focuses on the ethical and moral aspects of leadership than other leadership approaches, and therefore authentic leadership can foster ethical decision-making. Therefore, HR practitioners should partner with the organizational leaders in developing policies and procedures that actively support and encourage ethical behavior and promote justice within their organizations. Similarly, HR practitioners should implement programs creating a supportive work environment and building positive relationships among employees and between employees and supervisors.

To summarize, the findings showcase the need for organizations in the hotel and hospitality industry to establish programs that focus on leadership practices which improve employees' perceptions of organizational justice and, in turn, leads to positive organizational outcomes including reducing the considerable costs of employee turnover. It is also important that employees are aware of the policies and procedures and have a perception that they can connect and communicate to their supervisors and managers.

\section{Limitations}

The study relied on self-reported data which are a reflective recollection of the individual's experience. This may result in response bias, a widely discussed phenomenon in behavioral 
research where self-reported data are used. There are many reasons individuals might offer

biased estimates of self-assessed behavior, ranging from a misunderstanding of what a proper measurement is, to social-desirability bias, where the respondent wants to "look good" in the survey, even if the survey is anonymous. This is a cross-sectional study to be conducted in an uncontrolled field setting, thus precluding any inference of causal relationships among variables. The study is conducted over a certain interval of time and captures the responses dependent on conditions occurring during that time; a longitudinal design (with adequate time and resources) may better capture the change in perceptions over a period.

There was an underrepresentation of African American respondents, and thus the sample in this study was not reflective of general population of hotel employees. A perceived reason for such low response rate for African Americans may be a result of the method of survey administration delivered electronically through email. This may point to the fact that African Americans may be employed in positions which do not provide them with regular Internet access / emails and brings into picture the bigger issues of digital divide and access to technology. The constructs of organizational justice and authentic leadership are deeper than it could be measured by a scale; thus, quantitative research is a tool with limited scope. Finally, the surveys were not mobile-friendly which may have led to a decrease in the completion rate of the surveys.

\section{Conclusion}

The purpose of this study was to determine whether a relationship existed between authentic leadership and organizational justice perception among hotel employees. The results show that a strong degree of correlation exists between authentic leadership and organizational justice perceptions, and employee's perception of authentic leadership is a predictor of organizational justice. The hotel and hospitality industry are vital parts of the United States' economy; however, hotel industry is notorious for a demanding work environment, long work hours and low pay, which ultimately result in adverse behavioral and organizational outcomes including high levels of employee turnover. Research also found that hotel employees have most interactions (regarding pay, performance, procedures and others) with their supervisors, and a great deal of their organizational justice perceptions are formed through such interactions. Authentic leadership is a relative new leadership approach rooted in positive psychology, emphasizing on the ethical and moral aspects of leadership; the results of the study found that when employees perceive their leaders to be following the authentic leadership paradigm, they also perceive high levels of organizational justice. Authentic leadership has stronger relationships with informational and interpersonal dimensions of justice which implies that authentic leaders are strategic in their interactions with their employees. The results also imply that when employees studied in this research perceived justice in terms of procedures and outcomes, they believed that organizations determine those more than their supervisors. Finally, the results of this study may motivate hospitality/ hotel leaders to include authentic leadership development as an actionable strategy to bolster fairness and mitigate some of the negative features related to employment relationships in the industry.

\section{References}

Adams, J.S. (1965), "Inequity in social exchange", Advances in Experimental Social Psychology, Vol. 2, pp. 267-299, doi: 10.1016/S0065-2601(08)60108-2.

Ambrose, M.L. and Schminke, M. (2009), "The role of overall justice judgments in organizational justice research: a test of mediation", Journal of Applied Psychology, Vol. 94 No. 2, p. 491, doi: 10. 1037/a0013203. 
IHR

36,1

Avolio, B.J. (2007), "Promoting more integrative strategies for leadership theory-building", American Psychologist, Vol. 62 No. 1, pp. 25-33, doi: 10.1037/0003-066X.62.1.25.

Avolio, B.J. and Gardner, W.L. (2005), "Authentic leadership development: getting to the root of positive forms of leadership”, The Leadership Quarterly, Vol. 16 No. 3, pp. 315-338, doi: 10.1016/ j.leaqua.2005.03.001.

Avolio, B.J., Gardner, W.L., Walumbwa, F.O., Luthans, F. and May, D.R. (2004), "Unlocking the mask: a look at the process by which authentic leaders' impact follower attitudes and behaviors", The Leadership Quarterly, Vol. 15 No. 6, pp. 801-823, doi: 10.1016/j.leaqua.2004.09.003.

Avolio, B.J., Reichard, R.J., Hannah, S.T., Walumbwa, F.O. and Chan, A. (2009), "A meta-analytic review of leadership impact research: experimental and quasi-experimental studies", The Leadership Quarterly, Vol. 20 No. 5, pp. 764-784, doi: 10.1016/j.leaqua.2009.06.006.

Baldwin, S. (2006), Organizational Justice, Institute for Employment Studies, London.

Baum, T. (2013), International Perspectives on Women and Work in Hotels, Catering and Tourism, International Labor Organization, Geneva.

Berg, S. (2006), "Snowball sampling 1- Sequential estimation of the mean in finite population to Steiner's most frequent value", in Kotz, S., Read, C.B., Balakrishnan, N., Vidakovic, B. and Johnson, N.L. (Eds), Encyclopedia of Statistical Sciences, Wiley, Hoboken, New Jerssey, NJ.

Berger, F., Fulford, M.D. and Krazmien, M. (1993), "Human resources management in the 21st century: predicting partnerships for profit”, Hospitality Research Journal, Vol. 17 No. 1, pp. 87-102, doi: 10.1177/109634809301700108.

Bies, R.J. and Moag, J.F. (1986), "Interactional justice: communication criteria of fairness", in Lewicki, R.J., Sheppard, B.H. and Bazerman, M.H. (Eds), Research on Negotiations in Organizations, JAI Press, Greenwich, CT.

Blau, M. (1964), Exchange and Power in Social Life, Wiley, New York, NY.

BLS (2019), "Bureau of labor statistics occupational data", available at: https://www.bls.gov/cps/ cpsaat18.htm (accessed 27 March 2019).

Byrne, Z.S., Kiersch, C.E., Weidert, J. and Smith, C. (2012), "The justice-oriented face of organizations", in Sarlak, M.A. (Ed.), The New Faces of Organizations in 21st Century, NAISIT Publishers, Toronto, ON, Vol. 4, pp. 95-163.

Carbery, R., Garavan, T.N., O’Brien, F. and McDonnell, J. (2003), "Predicting hotel managers' turnover cognitions", Journal of Managerial Psychology, Vol. 18 No. 7, pp. 649-679, doi: 10.1108/ 02683940310502377.

Clapp-Smith, R., Vogelgesang, G.R. and Avey, J.B. (2009), "Authentic leadership and positive psychological capital: the mediating role of trust at the group level of analysis", Journal of Leadership and Organizational Studies, Vol. 15 No. 3, pp. 227-240, doi: 10.1177/ 1548051808326596.

Cohen-Charash, Y. and Spector, P.E. (2001), "The role of justice in organizations: a meta-analysis", Organizational Behavior and Human Decisions Processes, Vol. 86 No. 2, pp. 278-321, doi: 10. 1006/obhd.2001.2958.

Colquitt, J.A., Conlon, D.E., Wesson, M.J., Porter, C.O. and Ng, K.Y. (2001), "Justice at the millennium: a meta-analytic review of 25 years of organizational justice research", Journal of Applied Psychology, Vol. 86 No. 3, pp. 425-445, doi: 10.1037//0021-9010.86.3.425.

Colquitt, J.A., Greenberg, J. and Zapata-Phelan, C.P. (2005), Handbook of Organizational Justice, Lawrence Erlbaum Associates Publishers, Mahwah, New Jerssey, NJ.

Colquitt, J.A., Scott, B.A., Rodell, J.B., Long, D.M., Zapata, C.P., Conlon, D.E. and Wesson, M.J. (2013), "Justice at the millennium, a decade later: a meta-analytic test of social exchange and affect-based perspectives”, Journal of Applied Psychology, Vol. 98 No. 2, pp. 199-236, doi: 10.1037/a0031757.

Cottrill, K., Lopez, P.D. and Hoffman, C. (2014), "How authentic leadership and inclusion benefit organizations", Equality, Diversity and Inclusion: An International Journal, Vol. 33 No. 3, pp. 275-292, doi: 10.1108/EDI-05-2012-0041. 
Cropanzano, R., Bowen, D.E. and Gilliland, S.W. (2007), "The management of organizational justice”, The Academy of Management Perspectives, Vol. 21 No. 4, pp. 34-48, doi: 10.5465/amp.2007. 27895338.

Cut-Lupulescu, F., Dincu, A.M. and Borlovan, I.C. (2014), "The phenomenon of tourism and hospitality industry", Animal Science and Biotechnologies, Vol. 47 No. 2, pp. 297-300.

Leadership and organizational justice in hotel context

De Coninck, J.B. (2010), "The effect of organizational justice perceived organizational support, and perceived supervisor support on marketing employees' level of trust", Journal of Business Research, Vol. 63 No. 12, pp. 1349-1355, doi: 10.1016/j.jbusres.2010.01.003.

De Cremer, D. (2006), "When authorities influence followers' affect: the interactive effect of procedural justice and transformational leadership", European Journal of Work and Organizational Psychology, Vol. 15, pp. 322-351, doi: 10.1080/13594320600627662.

De Cremer, D. and Tyler, T.R. (2011), "On being the leader and acting fairly: a contingency approach", in De Cremer, D., van Dick, R. and Murnighan, J.K. (Eds), Social Psychology and Organizations, Routledge/Taylor \& Francis, New York, NY, pp. 39-65.

Demirtas, O. (2015), "Ethical leadership influence at organizations: evidence from the field", Journal of Business Ethics, Vol. 126 No. 2, pp. 273-284, doi: 10.1007/s10551-013-1950-5.

Dinh, J.E., Lord, R.G., Gardner, W.L., Meuser, J.D., Liden, R.C. and Hu, J. (2014), “Leadership theory and research in the new millennium: current theoretical trends and changing perspectives", The Leadership Quarterly, Vol. 25 No. 1, pp. 36-62, doi: 10.1016/j.leaqua.2013.11.005.

Drummond, K.E. and Murphy-Reyes, A. (2018), Nutrition Research: Concepts and Applications, Jones \& Bartlett Learning, Burlington, MA.

Faldetta, G., Fasone, V. and Provenzano, C. (2013), "Turnover in the hospitality industry: can reciprocity solve the problem? PASOS", Journal of Tourism and Cultural Heritage, Vol. 11 No. 4, pp. 583-595.

Folger, R. and Cropanzano, R. (2001), "Fairness theory: justice as accountability", in Greenberg, J. and Cropanzano, R. (Eds), Advances in Organizational Justice, Stanford University Press, Stanford, CA, pp. 1-55.

Folger, R., Cropanzano, R. and Goldman, B. (2005), "What is the relationship between justice and morality?", in Greenberg, J. and Colquitt, J.A. (Eds), Handbook of Organizational Justice, Lawrence Erlbaum Associates, Mahwah, NJ, pp. 215-245.

Fox, S., Spector, P.E. and Miles, D. (2001), "Counterproductive work behavior (CWB) in response to job stressors and organizational justice: some mediator and moderator tests for autonomy and emotions", Journal of Vocational Behavior, Vol. 59 No. 3, pp. 291-309, doi: 10.1006/jvbe. 2001.1803.

Fulford, M.D. (2005), “That's not fair! the test of a model of organizational justice, job satisfaction, and organizational commitment among hotel employees", Journal of Human Resources in Hospitality and Tourism, Vol. 4 No. 1, pp. 73-84, doi: 10.1300/J171v04n01_06.

Gardner, W.L., Avolio, B.J., Luthans, F., May, D.R. and Walumbwa, F. (2005), "Can you see the real me? A self-based model of authentic leader and follower development", The Leadership Quarterly, Vol. 16 No. 3, pp. 343-372, doi: 10.1016/j.leaqua.2005.03.003.

Garg, S. and Dhar, R.L. (2016), "Extra-role customer service: the roles of leader-member exchange (LMX), affective commitment, and psychological empowerment", International Journal of Hospitality and Tourism Administration, Vol. 17 No. 4, pp. 373-396, doi: 10.1080/15256480.2016. 1226151.

George, B. (2003), Authentic Leadership: Rediscovering the Secrets to Creating Lasting Value, JosseyBass, San Francisco, California, CA.

Gosser, K., Petrosko, J., Cumberland, D., Kerrick, S.A. and Shuck, B. (2018), "Organizational justice and socialization in a franchising context: factors influencing hourly workers' intent to stay", Small Business Institute Journal, Vol. 14 No. 1, pp. 1-18. 
IHR

36,1

\section{2}

Greenberg, J. (1990), "Organizational justice: yesterday, today, and tomorrow", Journal of Management, Vol. 16 No. 2, pp. 399-432, doi: 10.1177/014920639001600208.

Greenberg, J. (2006), "Losing sleep over organizational injustice: attenuating insomniac reactions to underpayment inequity with supervisory training in interactional justice", Journal of Applied Psychology, Vol. 91 No. 1, p. 58, doi: 10.1037/0021-9010.91.1.58.

Greenberg, J. (2011), "Organizational justice: the dynamics of fairness in the workplace", in Zedeck, S. (Ed.), APA Handbooks in Psychology. APA Handbook of Industrial and Organizational Psychology. Maintaining, Expanding, and Contracting the Organization, American Psychological Association, Washington, DC, Vol. 3, pp. 271-327, doi: 10.1037/12171-008.

Hannah, S.T., Avolio, B.J. and Walumbwa, F.O. (2011), "Relationships between authentic leadership, moral courage, and ethical and pro-social behaviors", Business Ethics Quarterly, Vol. 21 No. 4, pp. 555-578, doi: 10.5840/beq201121436.

Hemdi, M.A. and Rahim, A.R.A. (2011), "The effect of psychological contract and affective commitment on turnover intentions of hotel managers", International Journal of Business and Social Science, Vol. 2 No. 23, pp. 76-88.

Hiller, N.J., DeChurch, L.A., Murase, T. and Doty, D. (2011), "Searching for outcomes of leadership: a 25-year review", Journal of Management, Vol. 37 No. 4, pp. 1137-1177, doi: 10.1177/ 0149206310393520 .

Homans, G.C. (1958), "Social behavior as exchange", American Journal of Sociology, Vol. 63 No. 6 , pp. 597-606.

Hui, C., Lee, C. and Rousseau, D.M. (2004), "Employment relationships in China: do workers related to the organization or to people", Organization Sciences, Vol. 15, pp. 232-240, doi: 10.1287/orsc. 1030.0050 .

Hutcheson, G.D. and Sofroniou, N. (1999), The Multivariate Social Scientist: Introductory Statistics Using Generalized Linear Models, Sage, Thousand Oaks, California, CA.

Ibarra, H. (2015), "The authenticity paradox", Harvard Business Review, Vol. 93 Nos 1/2, pp. 53-59.

Ispas, A. (2012), "The perceived leadership style and employee performance in hotel Industry-A dual approach”, Review of International Comparative Management, Vol. 13 No. 2, p. 294.

Judge, T.A. and Colquitt, J.A. (2004), "Organizational justice and stress: the mediating role of workfamily conflict”, Journal of Applied Psychology, Vol. 89 No. 3, p. 395, doi: 10.1037/0021-9010.89. 3.395.

Karam, E.P., Hu, J., Davison, R.B., Juravich, M., Nahrgang, J.D., Humphrey, S.E. and Scott DeRue, D. (2019), "Illuminating the "face 'of justice: a meta-analytic examination of leadership and organizational justice”, Journal of Management Studies, Vol. 56 No. 1, pp. 134-171, doi: 10.1111/ joms.12402.

Kerfoot, K. (2006), “Authentic leadership”, Nursing Economics, Vol. 24 No. 2, pp. 25-26.

Kiersch, C.E. and Byrne, Z.S. (2015), "Is being authentic being fair? Multilevel examination of authentic leadership, justice, and employee outcomes", Journal of Leadership and Organizational Studies, Vol. 22 No. 3, pp. 292-303, doi: 10.1177/1548051815570035.

Leroy, H., Anseel, F., Gardner, W.L. and Sels, L. (2015), “Authentic leadership, authentic followership, basic need satisfaction, and work role performance: a cross-level study", Journal of Management, Vol. 41 No. 6, pp. 1677-1697, doi: 10.1177/0149206312457822.

Lopez-Cabarcos, M.A., Machado-Lopes-Sampaio-de Pinho, A.I. and Vazquez-Rodríguez, P. (2015), “The influence of organizational justice and job satisfaction on organizational commitment in Portugal's hotel industry”, Cornell Hospitality Quarterly, Vol. 56 No. 3, pp. 258-272, doi: 10.1177/ 1938965514545680.

Luo, Z., Marnburg, E. and Law, R. (2017), "Linking leadership and justice to organizational commitment: the mediating role of collective identity in the hotel industry", International 
Journal of Contemporary Hospitality Management, Vol. 29 No. 4, pp. 1167-1184, doi: 10.1108/ IJCHM-08-2015-0423.

Luthans, F. and Avolio, B. (2003), "Authentic leadership: a positive development approach", in Cameron, K. and Dutton, J. (Eds), Positive Organizational Scholarship: Foundations of a New Discipline, Berrett-Koehler Publishers, San Francisco, California, CA, pp. 241-261.

Leadership and organizational justice in hotel context

Luthans, F., Norman, S. and Hughes, L. (2006), "Authentic leadership: a new approach for a new time”, in Burke, R.J. and Cooper, C.L. (Eds), Inspiring Leaders, Routledge, London, pp. 84-104.

Martinson, B.C., Crain, A.L., De Vries, R. and Anderson, M.S. (2010), "The importance of organizational justice in ensuring research integrity", Journal of Empirical Research on Human Research Ethics, Vol. 5 No. 3, pp. 67-83, doi: 10.1525/jer.2010.5.3.67.

May, D.R., Chan, A.Y.L., Hodges, T.D. and Avolio, B.J. (2003), "Developing the moral component of authentic leadership", Organizational Dynamics, Vol. 32 No. 3, pp. 247-260, doi: 10.1016/S00902616(03)00032-9.

Megeirhi, H., Kilic, H., Avci, T., Afsar, B. and Abubakar, A.M. (2018), "Does team psychological capital moderate the relationship between authentic leadership and negative outcomes: an investigation in the hospitality industry?”, Economic Research, Vol. 31 No. 1, pp. 927-945, doi: 10.1080/1331677X.2018.1442234.

Meindl, J.R. (1989), "Managing to be fair: an exploration of values, motives, and leadership", Administrative Science Quarterly, Vol. 34 No. 2, pp. 252-276, doi: 10.2307/2989898.

Nadiri, H. and Tanova, C. (2010), "An investigation of the role of justice in turnover intentions, job satisfaction, and organizational citizenship behavior in hospitality industry", International Journal of Hospitality Management, Vol. 29 No. 1, pp. 33-31, doi: 10.1016/j.ijhm.2009.05.001.

Naumann, S.E. and Bennett, N. (2000), "A case for procedural justice climate: development and test of a multilevel model", Academy of Management Journal, Vol. 43, pp. 881-889, doi: 10.5465/ 1556416.

Neubert, M.J., Carlson, D.S., Kacmar, K.M., Roberts, J.A. and Chonko, L.B. (2009), "The virtuous influence of ethical leadership behavior: evidence from the field", Journal of Business Ethics, Vol. 90, pp. 157-170, doi: 10.1002/ejsp.2420150303.

Northouse, P.G. (2018), Leadership: Theory and Practice, 8th ed., Sage publications, Thousand Oaks, California, CA.

Pillai, R., Schriesheim, C.A. and Williams, E.S. (1999), "Fairness perceptions and trust as mediators for transformational and transactional leadership: a two-sample study", Journal of Management, Vol. 25, pp. 897-933, doi: 10.1177/014920639902500606.

Pless, N.M. and Maak, T. (2011), "Responsible leadership: pathways to the future", Journal of Business Ethics, Vol. 98, pp. 3-13, doi: 10.1007/s10551-011-1114-4.

Rego, A., Sousa, F., Marques, C. and e Cunha, M.P. (2012), “Authentic leadership promoting employees' psychological capital and creativity", Journal of Business Research, Vol. 65 No. 3, pp. 429-437, doi: 10.1016/j.jbusres.2011.10.003.

Rupp, D.E., Shapiro, D.L., Folger, R., Skarlicki, D.P. and Shao, R. (2017), “A critical analysis of the conceptualization and measurement of organizational justice: is it time for reassessment?”, Academy of Management Annals, Vol. 11 No. 2, pp. 919-959, doi: 10. 5465/annals.2014.0051.

Storberg-Walker, J. and Gardiner, R.A. (2017), "Authentic leadership in HRD_identity matters! Critical explorations on leading authentically", Advances in Developing Human Resources, Vol. 19 No. 4, pp. 350-361, doi: 10.1177/1523422317728731.

Strom, D.L., Sears, K.L. and Kelly, K.M. (2014), "Work engagement: the roles of organizational justice and leadership style in predicting engagement among employees", Journal of Leadership and Organizational Studies, Vol. 21 No. 1, pp. 71-82, doi: 10.1177/ 1548051813485437. 
IHR

36,1

Tabachnick, B.G. and Fidell, L.S. (1996), Using Multivariate Statistics, 3rd ed., Harper Collins, New York, NY.

Thibaut, J. and Walker, L. (1975), Procedural Justice: A Psychological Analysis, Erlbaum, Hillsdale, New Jerssey, NJ.

Tran, X. (2017), "Effects of leadership styles on hotel financial performance", Tourism and Hospitality Management, Vol. 23 No. 2, pp. 163-183, doi: 10.20867/thm.23.2.7.

Tsai, W.C., Chen, H.W. and Cheng, J.W. (2009), "Employee positive moods as a mediator linking transformational leadership and employee work outcomes", The International Journal of Human Resource Management, Vol. 20 No. 1, pp. 206-219, doi: 10.1080/ 09585190802528714.

Umphress, E.E., Labianca, G., Brass, D.J., Kass, E. and Scholten, L. (2003), "The role of instrumental and expressive social ties in employees' perceptions of organizational justice”, Organization Science, Vol. 14 No. 6, pp. 738-753, doi: 10.1287/orsc.14.6.738.24865.

Walumbwa, F.O., Avolio, B.J., Gardner, W.L., Wernsing, T.S. and Peterson, S.J. (2008), "Authentic leadership: development and validation of a theory-based measure", Journal of Management, Vol. 34 No. 1, pp. 89-126, doi: 10.1177/0149206307308913.

Warner, R.M. (2013), Applied Statistics: From Bivariate Through Multivariate Techniques, 2nd ed., Sage, Thousand Oaks, CA.

Yamak, O.U. and Eyupoglu, Ş.Z. (2018), "Leadership styles of hotel managers in Northern Cyprus: which style is dominant?", International Journal of Organizational Leadership, Vol. 7 No. 1, pp. 1-11.

Youssef-Morgan, C.M. and Luthans, F. (2013), "Positive leadership: meaning and application across cultures”, Organizational Dynamics, Vol. 42 No. 3, pp. 198-208, doi: 10.1016/j. orgdyn.2013.06.005.

\section{Corresponding author}

Deepu Kurian can be contacted at: dkurian3@uh.edu

For instructions on how to order reprints of this article, please visit our website:

www.emeraldgrouppublishing.com/licensing/reprints.htm

Or contact us for further details: permissions@emeraldinsight.com 